\title{
Education for the Social Services
}

\author{
MIRIAM HUTTON*
}

I have always been intrigued by the plastic button boxes which have several compartments and are so constructed that shaking the box is all that is required to sort the different sized buttons into the appropriate sections of the box. I wish that we could have such a box for sorting the educational dilemmas which face us in the social services. In the absence of such a box, I would like to explore some of the educational issues which affect the education of social workers and others who are employed in the social services.

Social workers have traditionally been considered as the primary staff for the social services. Indeed, social work has often been confused with or equated with the social services. In North America social work has been further identified as meaning professional social workers who have received their professional training in a post-baccalaureate programme in a university. In reality of course the majority of staff employed in the social services have not had professional social work training. Many "social workers" have received their training on the job. In fact the MSW (Master of Social Work) graduates formed an elite group, who though trained for practice, were very rapidly promoted to supervise, train, and administer. This contributed in part to the recent movement in Canada (and even more recently in the United States), to the development of undergraduate programmes for professional education in social work. In addition we have had, with the rise of the community college, new programmes of one and two year's duration which have produced "social service workers" or "welfare workers."

This diversity of preparation, while providing promise of more adequately meeting the needs of the social services, has produced some fragmentation and creates a number of problems.

If one thinks of the social services as a system, one can identify a range of personnel employed or utilized by this system (Briggs, 1973). These would include those directly involved in providing "human services" such as intake workers (who assist new applicants), supportive or counselling staff, community workers, treatment staff, educators, along with supervisors, co-ordinators, administrators and so on. (Of course people may often function in more than one capacity.) There may also be homemakers, foster parents, institutional house staff, child care workers, volunteers, and other staff from related disciplines such as home economics, psychology, nursing, and child development. Clearly this diversity in tasks, roles, and functions requires a corresponding diversity in education, or vocational preparation. For the purposes of this paper, however, I shall confine myself to those components of the system whose training is normally included in higher education. (A broader definition of higher education to include life long learning and all adult education would

\footnotetext{
*Assistant Professor, School of Social Work, University of Manitoba
} 
of course include many more components.) In this paper I shall refer to the formalized programmes attached to educational institutions such as community colleges and universities which offer vocational or professional education for entry into a human services career, or which provide advanced education for social workers. I exclude, for this paper, in-service training in agencies, and continuing education of a short term or non-formalized nature.

In 1972 at an international congress of schools of social work, Dr. Jan de Jongh presented a paper entitled "A Retrospective View of Social Work Education." In this he suggests that in North America, the tying in of social work education to the graduate level of the university has had negative effects. Among the negative effects he specifically notes are that "training is also restricted to a small number of students and made very expensive, thus creating social work as an elite profession," and also that "official social work training systems and their graduates were severed from the main stream of social activities and from the great and greatly needed mass of workers in the social field who all were in want of some kind of social knowledge and skill." Conversely he suggests that social work in England and Europe failed to develop fully social work methodology and professional competence because they were constituted at an undergraduate level. He then goes on to propose that in social work we need different levels of training with possibilities of movement from one level to another and that "the universities should be an organic element."

In the United States Werner Boehm $(1958,1968)$ had already predicted that social work education would need to concern itself with "preparing graduate, undergraduate, and even associate degree programs for the performance of less complex functions lying on the lower end of the professional continuum." This notion of a continuum was reinforced by Bisno (1959), Guzzetta (1972), and others, and as a result has begun to be talked of in social work education. It seems appropriate if one thinks of the undergraduate programme in social work being a foundation for the master's programme, which in turn is a foundation for even more advanced study. The major curriculum study (Boehm et al, 1959 to 1962) of the Council on Social Work Education even recommended that preparation for social work begin at the undergraduate level. However, this was rejected by the membership and until 1970 schools wishing accreditation for their social work programmes were required to have a two year programme at the master's level. This decision to hold the master's programme as an appropriate locus for professional education seems to be based on the assumption that social work is, or ought to be, professional, and that the complexity of both the social situations and the wide range of knowledge used by social workers requires graduate school preparation for practice (Abbott, 1931; Boehm, 1959; Campbell, 1967; Ripple, 1974). Probably concern over the maturity of graduates and some concern over professional identity and status were important here as well. The preoccupation with "profession," and the assumption that it is the norm is reflected in the terminology used to describe various levels of practice. Thus we find professional, pre-professional, sub-professional, para-professional, non-professional, and associate professional, all being used to describe people who are employed in the social services. The status acquired by being a professional is considerable. Perhaps for a vocational grouping composed mainly of women and dealing with the "unwashed and the unlovely" it was very necessary to strive for this in the past. Perhaps also in an age when even the obituary columns of most major newspapers have little meaning to most readers it is important to recognize that being a professional may help individuals to find a sense of identity and purpose in a world which is increasingly complex and imper- 
sonal. But to have a professional category implies an elitism which runs contrary to the egalitarian thrust of our times. In the social service system it implies superior or inferior status for employees. This dilemma has produced problems in morale, particularily for lower status personnel. This is no doubt compounded if agencies are not clear about roles and expectations, and do not differentiate tasks clearly.

In any case the assumption that education for the social services was synonomous with professional education for social work, which in turn was seen as graduate level preparation, has had profound implications. If one accepts this, one defines professional practice and then redefines practice for the other levels in response to this. For example, professional practice might be seen to include a specialized body of knowledge and skill, relative autonomy in decision making, a code of ethics, and a commitment to service, and to continuous learning. The para-professional then might be expected to have a lesser body of knowledge and skill, less autonomy in decision making. Because he is assumed to work under a professional, he might not be required to develop his own code of ethics, and to be less concerned with service or educational goals.

An alternative approach might be to examine the value base and philosophical stance appropriate to the whole of the social service system, and to then examine what is required to provide social services to society. We can then designate diverse functions within this for which appropriate educational provision could be made. In this approach the professional nature of social work is played down, and the differentiation of tasks and functions for each grouping employed in the social services becomes more important.

We can think therefore of social work education or we can think of education for the social services. The one implies professional education with pre-professional and postprofessional components. One can argue about whether or not baccalaureate education is professional or pre-professional, and whether or not one requires a generic core, or foundation, and whether or not specialization ought to occur at the master's level or at the post-master's level. The community college is designated as providing an inferior or sub-professional training which is considered adequate for some tasks. (One can see why this may be threatening to some social workers, who see the community college as debasing professional education.) The alternative is to consider education for the social services, requiring a range of personnel with a variety of educational backgrounds, each with a unique identity and legitimate functions and roles (Austin, 1972; Briggs, 1973; Segal, 1974). (A parallel from the health services would be that medicine, nursing, physiotheraphy, occupational therapy, and pharmacy all have a distinctive place in the health services system.) The term continuum would not be appropriate for this alternative because the individual components are not necessarily dependent on each other. Perhaps one could use the word network to denote the relationship among the components.

In my view, the failure to distinguish between social work education and education for the social services compounds the issues of curriculum, articulation, accreditation and certification, admission and access, and ultimately of employment of graduates, for all institutions which are involved in educating people who will staff the social service system.

\section{Curriculum}

Curriculum is very directly affected by the purposes, functions, and structures of the programmes it is designed to serve. Entwistle (1970) has argued that vocational preparation is 
a legitimate function of education. Trow (1974) suggests that higher education performs three basic functions: first, the selection and formation of governing elites; second, the training of "highly skilled people .... required by a highly complex society and its institutions;" and third, to educate a "whole society to be adaptable to rapid social and economic change." The second function seems to be most appropriate as a goal for educational programmes for the social services. Trow notes as well that the division of labour and diversity required to maintain different functions is in conflict with the egalitarian forces, and that it is difficult if not impossible to have both diversity and equality. This has direct bearing on the provision of diverse programmes to meet diverse functions in the social services. Some might argue that the professional belongs to the elite rather than the highly skilled group, but perhaps the elite function in the social services might more properly be assigned to the leaders of the profession (and by implication, these might be educated in the advanced programmes of the universities). Perhaps some of our dilemma over elitism stems from conflict in providing opportunities to improve status as opposed to providing opportunities to develop leadership.

If one assumes a professional purpose, the curriculum will need to reflect this purpose. In North America professional education has a long tradition of association with the university. On the other hand "technical" training is more likely to be associated with the community or technical college. If the community college is seen as a stepping stone to further education, as in the province of Quebec, then clearly the curriculum will need to reflect this. If, however, the intent is to provide an alternative educational experience, as in Ontario, this needs to be identified and the curriculum should reflect this difference. One or two year programmes which are directed to skill development and the acquisition of specific knowledge seem to be appropriate for the community college. Where a broader understanding and commitment to values, ethics, and service are required the university would seem appropriate. For example, a social service worker who is employed in a financial assistance programme would need to know the programme and its specific provisions well. He will also need to know something about other community resources. He will not likely need to know the historical and philosophical basis for social assistance programmes in Canada, or how to evaluate or modify social assistance programmes. But this would all be required of a more senior employee in the same agency, and we would generally associate this with the educational requirements of a professional social worker.

When professional education is provided at an undergraduate level one might expect that it will contain a liberal arts component. The measure of liberal arts, or of other nonvocational knowledge, which is included in either university programmes or in community college programmes will presumably reflect the ultimate purposes of such programmes. Community colleges, more than universities, might also be expected to reflect local interests and requirements.

De Jongh (1972) points out that social work began by being concerned both with improving societal conditions and with delivery of service. Very early the lack of congruence between these two perspectives forced people to make a choice. In North America this has resulted in a greater concern for the individual, and in the development of a methodological and skill base in working with individuals. This was undoubtedly facilitated by the fact that the social agencies were closely linked to the schools of social work and provided a major part of the educational experience for students. Many schools, including my own in Manitoba, 
were begun as a direct result of agencies requiring trained manpower. The linkage of agency and social service community with school has been extremely strong (Dolgoff, 1974). The issue of whether to educate providers of service, or social critics and societal change agents has continued unresolved. Only recently, I heard a very articulate social work student at a conference on social work education, repeat again this dilemma of education for service, or for change.

The 1959 Curriculum Study of the Council on Social Work Education (Boehm et al, 1959 to 1962) recommended the adoption of "sequences" as an organizing principle for curriculum. This has meant that content has been classified into five areas or sequences - Human Behaviour and Social Environment, Social Welfare Services, Social Work Practice, Research, and Field Work. Social Work Practice was further delineated by methodology to be either Case Work, Group Work, Community Organization, or (rarely) Administration. This pattern still exists in many schools and can be seen emerging in the subjects taught in some community colleges as well. An alternative curriculum pattern, which was popular earlier, to organize curriculum by fields of practice (corrections, child welfare, etc.) has recently been revived and can be noted in programmes of different levels.

The strong North American emphasis on methodology has prevaded even the above mentioned structures. Indeed Field Work which might be expected to provide the student with an opportunity to test himself as a developing professional social worker, or as a developing social service worker, is very often identified, either explicitly or implicitly, as an opportunity for the student to experience Practice methodology. Thus, the student graduates assuming that the field experience which has reflected a particular methodological orientation has also provided him with a sample of professional experience. Over the years this distortion has reinforced the methodological influences which de Jongh noted. But this has also meant a weakened understanding of the fundamental purposes of the social services, and a skewed professional identity for many social workers who saw themselves as case workers or group workers rather than social workers. This imbalance needs to be addressed in any attempt to provide educational programmes for the social services.

One recent attempt to resolve these dilemmas has been through the generalist approach to social work education (Dea, 1972; Westbury, Simon, \& Korbelik, 1973; Grosser, 1974; Dolgoff, 1974). Some schools have attempted to prepare students very broadly for intervention in social situations, so that they can intervene on behalf of clients both at the personal and at the societal level. Sometimes this "generic base" has been seen as appropriate for the first year of a two year master's programme, and fairly frequently as suitable for undergraduate social work education. In the implementation of a generalist approach, however, programmes have been hampered by the scanty theoretical base which has so far been developed, and by a variety of definitions for the term generalist (Westbury et al, 1973; Ripple, 1974). This has been compounded by the very real difficulty of retooling faculty who have not previously been trained in this approach to social work (Westbury et al, 1973). Thus far the generalist base has sometimes emerged as a holistic, integrated approach, and sometimes as a combination of the earlier methodologies (Case Work, plus Group Work, plus Community Organization), and in some instances as a slightly broader base for work in one of two streams (micro - work with individuals, families, and small groups, or macro - work at the community or social policy level). With the two streams we see again the difficulty of educating both for service delivery to individuals and 
for societal change. (This may also reflect the strength of the methodologies mentioned earlier, and also the difficulty in implementing major curricular innovations.)

During the past decade Canadian social services and social work have become increasingly differentiated from those in the United States. This has led to separate accreditation and professional associations. Of the twenty Canadian schools of social work the majority are now commited to an undergraduate programme for basic professional education; sixteen schools are currently offering or preparing to offer BSW (Bachelor of Social Work) programmes, three schools offer basic professional training at the MSW (Master of Social Work) level (some schools are in transition), and some half a dozen offer an MSW as a second degree for those who have previously taken their professional education at the BSW level. At the present time the only Canadian school with a doctoral programme in social work is at the University of Toronto; both McGill and Toronto, however, have a one year advanced diploma programme for post master's study.

Ryerson Institute of Technology is in a unique position because it is not affiliated with the Canadian Association of Schools of Social Work, and because it has both a two year diploma course for social service workers and an undergraduate degree programme in social work. (Graduates of the diploma course who have worked for one year or longer may take an additional two years of study for a BAA - Bachelor of Applied Arts) Community colleges are not eligible for affiliation in the Canadian Association of Schools of Social Work. In some instances, notably the twelve community colleges in Ontario which have social service worker programmes, community colleges have formed their own association. In so far as curriculum ideas are shared from one institution to another, or staff move, or students attempt to transfer these various structural arrangements will affect the curriculum which may emerge in any given institution.

The lack of clarity and confusion around purpose, which was noted earlier in the schools of social work, is even more apparent if one considers the social service worker or social welfare worker programmes as well. These programmes, growing up very quickly and in a short space of time, have had to develop without the benefit of research or much curricular expertise. In most instances faculty recruited have not had prior experiences in social work education or in curriculum development. The model which one might expect these faculty to choose would likely be their own MSW educational experience. In fact a perusal of several calandars for social service worker programmes in Ontario would appear to support this. This has resulted in curricula for community colleges, in Ontario at least, which resemble watered down MSW programmes of the late 1950's and early 1960's. They are caught up in teaching the familiar methodologies of Case Work, Group Work, and Com. munity Organization. Ironically this has occurred at the same time as schools of social work, particularily in Canada, have been moving away from a methodological approach. This means that the community college graduate will have training that is compatible with current practice in agencies which are still staffed primarily by graduates of an earlier period, but may be increasingly incompatible with the social work philosophy and practice of newer graduates of Canadian schools of social work. While the university graduate is being given a theoretical base which will hopefully equip him to understand and adapt to a variety of practice situations, the community college graduate with a shallower theoretical base may be more vulnerable to obsalesence. 


\section{Articulation}

Graduates of undergraduate programmes in social work are currently not able to take advantage of MSW or graduate programmes in social work at Toronto, Wilfred Laurier, or Carleton because both the undergraduate BSW and these graduate MSW programmes are designed to provide basic professional education. Students who wish to take advanced professional education following a BSW must select a school which has both a BSW and an MSW programme. This means that there is a great deal of confusion in the minds of students, agencies, and the general public about the differences and relative value of the different programmes. The difficulty in differentiating between the various programmes has been complicated by the threats to status which many MSW's currently in practice feel. The Urwick - Currie report demonstrates this confusion in their deliniation of possible jobs for people trained in the various programmes, and in the comments of employers re hiring preferences.

An additional problem in articulation between the undergraduate and traditional MSW programmes might develop as undergraduate schools provide professional social work education to people who already have a BA. At Manitoba, for example, some twenty places had been reserved for opters-in with advanced standing, for the academic year of 1974-75. Well over a hundred applications were received for these places, and of these applicants some sixty-eight had a BA. It is too early to tell whether this may be a new trend. (I have been interested too in the number of BSW students who have mentioned that they hoped to complete both their BSW and BA degrees.) One might assume that two years to obtain a BSW after completion of a BA has some equivalency with a two year MSW taken as a first professional degree following a BA. Holders of an MSW which has been taken following a BSW and some years of practice might well argue that their training is superior to an MSW which encompasses only basic professional training. The issue of BSW vs MSW may become even more important if subtle pressures are put upon practitioners to have an MSW. These seem to exist, particularily in Ontario. For example, I recently met an MSW student in Toronto who had chosen the MSW route "just in case," and another student from Atkinson College who hastened to tell me that she planned to get her MSW as soon as she graduated. These educational pressures may be counterproductive in meeting the needs of either the students, the social service system, or of society.

If the undergraduate and graduate programmes in social work are not always compatible, the problem is compounded for the graduate of the community college. The disparity mentioned earlier makes movement into an undergraduate programme with any hope of advanced standing very difficult. If the intent of the community college is to provide alternative education to the university, this may not be incongruous. However, the UrwickCurrie report suggests that some $15 \%$ of community college graduates in Ontario continue on to university with in the first two years after graduation. This suggests that either we are not assisting students in making the best choice of which programme to enter or that the pressures mentioned earlier are affecting community colleges as well as schools of social work. It also might reinforce the need for clearer role identification, and curricula to match these roles. This clearer definition of role and curriculum would also facilitate the identification of what students might already know, or not know, and thus facilitate better articulation when it was appropriate to move from one programme to another. Articulation 
between the variety of programmes and institutions is a major issue. It is heightened by the changing patterns of student attendance: the student who drops out temporarily, the student who moves from one geographic area to another, the student who wishes to combine more than one discipline, the mature student who returns after some years of employment, and the part time student.

\section{Accreditation and Certification}

Canadian schools of social work are now accredited through the Canadian Association of Schools of Social Work. Accreditation procedures are costly and time consuming, and there is not consistent agreement about the value of accreditation. While educators argue about the merits and costs of accreditation, students tend to be very concerned. Manitoba students, for example, were able to move faculty to reverse their decision against accreditation of the MSW programme because they feared that entry into advanced study or special employment opportunities might be lost to them if they had not been graduated from an accredited programme. Because of the newness of the undergraduate programmes which are common in Canada now, and the newness of the schools themselves in some instances, the criteria and the standards have been difficult to establish. This has been compounded by the regional and philosophical differences which characterize Canadian schools and that the Association and its membership value. However, most Canadian schools appear to be seeking accreditation. The small number of schools and the relatively close relationships which exist between schools and faculty pose some problems however. There is only a small body to draw on for examining personnel, and they may not all be fully knowledgeable about the type of programme which they are attempting to examine. Criticism, qualifications on accreditation acceptance, or refusal to accredit may produce strains in a small association. The separation in structure and organization between the universities and the community colleges, excludes them from accreditation.

Certification of individual professionals with respect to their professional competence is even more difficult. The Commission on Post-Secondary Education in Ontario, in examining certification, states,

As a society we seem obsessed with qualifications; we accept them uncritically as proof of competence and those who lack them are rejected, or at least suspect, regardless of experience or personal qualities. Too little attention is paid to the actual requirements for a job. In effect the symbols of certification have come to be accepted as the reality they supposedly represent.

A diploma or degree has become the recognized form of certification, even though this is actually a measure of academic success, and at best a predictive statement about future competence. Unlike the medical and legal professions, social work does not have the legal sanction to restrict practice to certified or licenced members. In part this stems from the difficulty which social workers have had in delineating an exclusive area of expertise. Certification is a provincial matter. Membership in professional social work associations has sometimes been limited to graduates of recognized schools of social work, although in some provinces they have also included graduates of a community college, and sometimes practitioners who have been trained on the job. Additional attempts to certify by separating 
the certification function from the professional association have not met with outstanding success. In Manitoba, for example, the Manitoba Institute of Registered Social Workers has not achieved more than voluntary status, and a limited membership. They have had difficulty in establishing criteria for competence and have tended without much question to accept for membership those who have a degree and one year's work experience. While such institutes and associations attempt to respond to breaches of a code of ethics, they have not been able to protect the public from incompetence.

This failure to establish certification procedures which can demonstrate competence for practice has left a major responsibility with the educational institutions. In the absence of other certification procedures, the successful completion of a recognized course of study remains the major evidence that employers and the general public are able to use.

\section{Access}

The lack of certification procedures places special strains upon institutional admission policies. There is an underlying assumption that students who graduate from any given programme will in fact be suitable candidates for employment in the social services. This implies, too, some meshing of numbers and types of graduates with the needs of the prospective employers. Until very recently it was assumed that the social services could absorb as many people as the schools could train. This is no longer true. The financial realities of the seventies coupled with the very rapid expansion of programmes training human service workers may mean that the number of students trained in all programmes may need to be controlled or limited. In addition, other economic factors may also influence. For example, student quotas, limitations on faculty size, availability of educational resources (particularily field instruction), and the high cost of training certain groups such as the inexperienced, young student, or the mature student who comes with educational gaps, or the extra attention required for the extremely weak or failing student, must all be considered. In this regard it is interesting to note that the faculty of the Regina School of Social Work felt that the young, inexperienced student required three times as much faculty time as older, experienced students. They might have resolved this by limiting access to those who already had work experience. Instead they have arranged for all of their young students to stop out for a year and work. Certain community colleges such as Conestoga, in Kitchener, Ontario have handled this problem by admitting only students who are mature and who have had work experience. This admission policy is encouraged by the Urwick-Currie report, which notes the difficulty young community college graduates have had in obtaining employment. In an era when unemployment of young people is a problem, and when the government has attempted to encourage young people to remain in school, this presents educational institutions with a conflict in purpose.

In addition, many institutions include personal suitability as a requirement (the Commission on Post-Secondary Education in Ontario noted with concern the lack of attention that most professional programmes paid to this matter). In the human service occupations, almost all personnel work with people and for this certain personal qualifications are required, such as the ability to relate to others, to communicate verbally, to convey warmth and concern. Conversely, rigidity, coldness, impulsiveness, or unwillingness to become involved with other people might be considered as unacceptable personal characteristics. Screening several hundred applicants for these characteristics is a very demanding and costly process. Admis- 
sions policy is necessarily predictive: predictive both with relation to the student's potential within the institution, and later in practice (Brigham, 1968). Unfortunately there is little empirical evidence to guide institutions in this process. In fact, Brigham has suggested that schools of social work may tend to admit conforming students. (As an impetus to selecting more creatively, he provides a list of some eighty-four characteristics which identify highly creative persons.) We see here the linkage between admission policy and the expected role outcome which is anticipated for the graduates of a particular institution. One might assume that the requirements will be different for a child care worker in an institution, a team leader in a social agency, and a social work researcher. As the various curricula and functions of different practioner levels emerge, the admission requirements may change also.

All of these limitations on access run counter to the emerging trend of mass education and egalitarianism (Oliver Report, Manitoba, 1973; Boyer, 1974; Trow, 1974; to name a few). One might consider the policy of broadening access and providing weeding out procedures at a later date. This "revolving door" policy, while appearing to be more democratic, is costly both to students and to institutions.

Both the Oliver report and Boyer discuss the problem of access with regard to specific groups of students. If one thinks of access for high school students one notes the usual advantage of urban, bright, middle class students in competition for places in the university. However, my own informal surveys of students entering social work in Manitoba is that roughly half come from outside of Winnipeg, and there is a substantial number of students from non-middle class backgrounds. Perhaps social work attracts a somewhat broader group than most university courses. At the community college level it is interesting to note the recommendation (previously mentioned) of the Urwick-Currie report that students be discouraged from applying directly from high school. Minority group students probably fare better in social work and in social service worker programmes because of the frequent involvement of the social services with minority groups. Certainly women are well represented. Native people may sometimes be admitted with reduced entrance requirements: both Manitoba and Saskachewan have special social work programmes planned for native peoples in centres which are geographically accessible to them. My own concern is not the difficulty of access for these people but rather that we may be imposing an educational and social service system on people which is not appropriate to their culture or needs. The working adults are probably the group most discriminated against in the educational programmes under discussion. Most institutions offering training in the social services do not facilitate part time or evening study for working adults. Programmes normally conform to the usual academic year and are highly structured as to content and order. Field instruction, for instance, presents special problems for the part time or employed student. One Canadian institution, which has made an attempt to facilitate study for the working adult is the Regina School of Social Work. This school has designed an external programme which is highly flexible, which provides for assessment of experience for academic or field work credit, and which has no residence requirement. Courses are offered in different geographic locations and the School has attempted to negotiate with employers to obtain release time for employed students. While originally seen as a temporary measure to accomodate local adults who had not been able to take advantage of educational opportunities earlier, the continued numbers of students enrolling seem to indicate that this is meeting a very real need. It is interesting to note, however, that catering for unemployed adults has had a 
different effect, at least in Manitoba. The Red River Community College has withdrawn its programme in social welfare, in part because the faculty in the programme felt that it had become a dumping ground for retraining adults under Canada manpower grants. In this instance the funding power of the training programmes outweighed any admission requirement of personal suitability.

\section{Staffing and Finance}

With the financial stringencies of the seventies growing more and more apparent, it may be useful to look at a few of the implications of staffing, and the financial stresses on the educational programmes under discussion.

The development of new and innovative programmes, while stimulating and exciting, requires time, energy, and money. Continuous change, however, may be exhausting. But change, in large measure, is already upon us. The faculty who are now teaching in schools of social work were educated in case work, group work, or community organization but probably teach in a programme which has an integrated methods or generic approach. Faculty in community colleges were trained as social workers or in other disciplines, but not as social service workers. Few of either group have had training in education. "Retooling," making a shift in identification, aquiring new knowledge takes time. If this is not budgeted for, the curriculum may suffer. Where there are incongruities, the student may be confused rather than educated. The practicum, or field instruction, may be especially vulnerable, particularily if taught by agency personnel who have not had opportunities to integrate new approaches and content. The cost of field instruction is high and may be questioned by universities, colleges, and agencies who are facing budgetary cuts. The thrust of new educational programmes and changes in methodology, however, underscores the importance of the educational aspect of field instruction and the need for faculty field instructors. While the role of the practicum is generally recognized for basic vocational education, its value in advanced courses is less clear.

The differences in student-faculty ratio between graduate, undergraduate, and community college programmes may well exert pressures on curriculum, faculty morale, and quality of education. For example, those schools which have retained the MSW as the first professional degree, may well be under pressure from their universities to move toward a (less expensive?) undergraduate programme; philosophically they may wish to, but the realities of staff reduction which would accompany such a move, make this choice unattractive. On the other hand, schools with only undergraduate programmes in social work may look at the more generous staffing allocation of graduate programmes and push toward expansion of their offerings without careful consideration of the needs of the social services. We see also many new programmes emerging in universities and community colleges, which while locally useful may put a strain on faculty and other educational resources, or which may produce imbalances in the system. While we give lip service to the BSW as the basic professional degree, we may promote MSW programmes for financial reasons, thereby undermining the image we are attempting to establish for the BSW.

Since graduate faculty have time for research and social criticism, one may expect to see differences in emphasis between graduate schools and undergraduate schools; presumably the former may be more focused on societal change rather than just on meeting the needs of professional practice. If faculty in community colleges are carrying heavier teaching 
loads, they too may be unable to find "reflective time" or to keep up with a rapidly changing knowledge base. This may result in an unintentional narrowing in their teaching. In addition the Urwick-Currie report (1974) noted the large turnover of coordinators in the Ontario social service worker programmes and speculated that this may have had a negative effect.

\section{Courses in Social Welfare}

There is an additional complication which while not directly related to education for the social services needs to be considered at the same time. There is confusion in the literature, and from one institution to another, about the term social welfare, with the result that it is sometimes used with a professional or vocational connotation and sometimes used to refer to the institution of social welfare. I prefer to use social work or social service worker where a vocational intent is implied, and to use social welfare to refer to the institution, or the social services. I have used social services to refer to the system requiring manpower, so that we may distinguish that area of study which is commonly termed "social welfare," from the social service system which is the major concern of this paper. Using this designation Social Welfare becomes a component in the education of social workers, social service workers, and others. This is of course a somewhat arbitrary distinction but one which may simplify discussion.

In addition to courses in Social Welfare in professional programmes in the university, we may also have a variety of courses offered at a university which have social welfare as a main theme. These might be "The economics of Social Welfare" or "History of the Social Welfare System in Canada." While these courses might be vocationally useful, they do not necessarily have a vocational objective. Often, they are under the sponsorship of the Faculty of Arts, or they may be in a professional programme but be open to other students. We may think of these courses as having a general educational thrust. Recalling the three functions which Trow specified for the university, these courses would seem to be a part of that education which is intended to educate a "whole society to be adaptable to rapid social and economic change." This has often been advocated as a purpose for undergraduate education in social work as well (Council on Social Work Education, 1967; Loewenberg, 1969; Witte, 1969), but it seems to me to be confusing to attempt both professional education and general education in the same programme. Therefore I would advocate the separation of the two functions. For this, we could develop two parallel streams, with the one offering professional preparation at three levels (BSW, MSW, DSW), and the other offering education in the field of social welfare. While most likely to be seen as a minor or major for undergraduate study, we might also have programmes at the usual three levels, BA, MA, PhD. This would relieve the professional schools of providing the more expensive professional training to students who intend to move on to other specializations such as law, administration, or research. It could also provide some flexibility for the student in other disciplines who needs some background in social welfare, or who is not fully committed to a vocation in social work.

Some universities might provide only the social welfare stream, while others might provide only the professional stream. Many of the courses in social welfare would, of course, be excellent background for professional students in social work, and might be designated as either required or elective, in the same way in which one might require courses in sociology or psychology. They might, therefore, be taught by faculty who have joint appointments 
in both social work and social welfare. In some instances departments might be designated by the double title, although this might prove confusing. Some universities may elect to provide different combinations of the two streams, such as undergraduate programmes only or graduate programmes only.

The greater variety of programming which these parallel offerings would provide would be especially helpful to those who hope to teach either at the community college or the university, or to those who plan senior level careers in public welfare administration, or research.

\section{Conclusion}

This paper has attempted to examine some of the issues affecting education for the social services. The preoccupation with profession, or social work, is noted and the diversity in manpower needs for the social service system is identified. The suggestion is made that we need to examine the roles and functions of all the personnel employed in the social service system so that we may develop appropriate educational programmes to meet the needs of these diverse functions.

Some of the implications and dilemmas facing institutions of higher education in providing such programmes have been looked at. In addition, the issue of educational programmes in social welfare has been introduced, and the suggestion made that we move toward two streams, a vocational or professional stream, offering BSW, MSW, DSW degrees and a general educational stream in social welfare leading to a BA, with specialization in social welfare leading to an MA and PhD. 


\section{References}

Abbott, Edith, Social Welfare and Professional Education. Chicago: University of Chicago Press, 1931. Aptekar, Herbert H., "The Curriculum-Building Process," Journal of Education for Social Work, Vol. 4, No. 2 (Fall 1968).

Association of Universities and Colleges of Canada. Seminar on Training Programmes in the Social Services at the Post-Secondary, Non-University Level, Ottawa, 1969.

Barker, Robert L., and Thomas L. Briggs, Differential Use of Social Work Manpower, New York: National Association of Social Workers, 1968.

Bisno, Herbert, The Place of the Undergraduate Curriculum in Social Work Education, New York: Council on Social Work Education, 1959.

Block, Alvan M., "The Dilemma of Social Work Education: Restructuring the Curriculum," Journal of Education for Social Work, Vol. 8, No. 1 (Winter 1972).

Blum, Arthur. "Differential Use of Manpower in Public Welfare," Social Work, Vol. II (Jan. 1966), pp. 16-21.

Boehm, Werner W. "Common and Specific Learnings for a Graduate of a School of Social Work," Journal of Education for Social Work, Vol. 4, No. 2 (Fall 1968). ed., Curriculum Study for Social Work Education. New York: Council on Social Work Education. Volumes I-XIII, 1959-62.

"Manpower Planning in Social Welfare," Journal of Education for Social Work, Vol. 6. No. 1 (Spring 1970), pp. 11-20.

Boyer, Ernest L. "Access and Public Support," In James A. Perkins, ed., Higher Education: Crisis and Support, New York: International Council for Educational Development, 1974.

Brawley, Edward Allan. Community and Social Service Education in the Community College, New York: Council on Social Work Education, 1972.

Briggs, Thomas L. "Social Work Manpower: Developments and Dilemmas of the 1970s," in Margaret Purvine, ed., Educating MSW Students to Work with Other Social Welfare Personnel, New York: Council on Social Work Education, 1973.

Brigham, Thomas M. "Philosophical Issues and Trends in Student Selection Today," Journal of Education for Social Work, Vol. 4, No. 2 (Fall 1968).

Campbell, Thomas F., SASS: Fifty Years of Social Work Education, Cleveland: Case Western Reserve, 1967.

Council on Social Work Education, Continuities in Undergraduate Social Welfare Education, New York: Council on Social Work Education, 1969.

Daly, Dorothy Bird, "The Future Baccalaureate Degree Social Worker - Implications for Social Work Education," in Continuities in Undergraduate Social Welfare Education, New York: Council on Social Work Education, 1969.

Dea, Kay, ed., New Ways of Teaching Social Work Practice, New York: Council on Social Work Education, 1972.

de Jongh, Jan. "A Retrospective View of Social Work Education," in New Themes in Social Work Education: Proceedings of the XVI International Congress of Schools of Social Work, The Hague: I.A.S.S.W., August 1972.

Dolgoff, Ralph, Report to the Task Force on Social Work Practice and Education, New York: Council on Social Work Education, 1974.

Entwistle, Harold. Education, Work and Leisure, London: Routledge and Kegan Paul, 1970.

Griffin, Virginia, Freedom and Frustration in the Professional School; An Evaluation, School of Social Work, University of Toronto, Toronto: Ontario Institute for Studies in Education, Occasional Paper \#1, 1969.

Guzzetta, Charles. "Curriculum Alternatives," Journal of Education for Social Work, Vol. 8, No. 1 (Winter 1972). pp. 24-30.

"The Curriculum Continuum," in Michael J. Austin, ed., Curriculum Building for the Continuum in Social Welfare Education, Tallahassee: State University System of Florida, 1972.

Grosser, Shirley, "Educating the 'Holistic' Social Worker: A Perspective and an Approach for Practice." 
Paper given at the 1974 Conference of the Canadian Association of Schools of Social Work, May 1974.

Halmos, Paul, The Personal Service Society, Cardiff: University of Wales, 1966.

Kaslow, Florence W., et al., Issues in Human Services, San Francisco: San Francisco State College, 1972.

Loewenberg, Frank M., "Designing an Undergraduate Social Welfare Program for the Nineteen Seventies," in Continuities in Undergraduate Social Welfare Education, New York: Council on Social Work Education, 1969.

Loewenberg, Frank M., and Alfred Stamm, "Standard Setting in Social Work Education," in The Current Scene in Social Work Education. New York: Council on Social Work Education, 1971.

Madison, Bernice, Undergraduate Education for Social Welfare, San Francisco: San Francisco State College, 1960.

Manitoba Institute of Registered Social Workers, Report of the Membership Committee, January, 1972.

Manitoba, Report of the Task Force on Post-Secondary Education in Manitoba, Michael Oliver, Chairman, Winnipeg: Queen's Printer, 1973.

McPheeters, Harold L. and Robert M. Ryan, $A$ Core of Competence for Baccalaureate Social Welfare and Curricular Implications, Atlanta: Southern Regional Education Board, 1971.

McGlothlin, William J., The Professional Schools, New York: the Center for Applied Research in Education, 1964.

Commission on Post-Secondary Education in Ontario, The Learning Society, Douglas T. Wright, Chairman, Toronto: Ministry of Government Services, 1972.

Ripple, Lillian, ed., Innovations in Teaching Social Work Practice. New York: Council on Social Work Education, 1970.

Report to the Task Force on Structure and Quality in Social Work Education, New York: Council on Social Work Education, 1974.

Segal, Brian., "The Helping Continuum: Differential Social Welfare Manpower Utilization in Health," Social Worker, Vol. 42, No. 2 (Summer, 1974).

Trow, Martin, "Reflections on the Relations Between the Occupational Structure and Higher Educational Systems," in James A. Perkins, ed., Higher Education: Crisis and Support, New York: International Council for Educational Development, 1974.

Urwick, Currie and Partners Ltd., Study for Ministry of Colleges and Universities, Study of the Social Service Worker Programs in Ontario Colleges of Applied Arts and Technology, 1973.

Westbury, Ian, and Bernece K, Simon and John Korbelik, eds., The Generalist Program: Description and Evaluation. Chicago: The School of Social Service Administration: the University of Chicago, 1973. 